\title{
An introductory report on the use of Bioplast in ophthalmic surgery
}

\author{
ATTILA CZIGÁNY \\ From the Ophthalmic Ward, Hospital No. 2, Zala County Council, Nagykanizsa, Hungary
}

SUMMARY Bioplast is an excellent material for implants. It lends itself readily to cutting and suturing and is easily applied. It is highly suited to ophthalmic surgery. It has the great advantage of having no antigenic properties and is quickly absorbed. Our cases recovered without complications, and the results were satisfactory both functionally and cosmetically. For these reasons we recommend Bioplast in ophthalmology.

Conjunctiva may be replaced by many other tissues, as reviewed by Collin (1975). In 1955 Gerendás prepared a plastic-like film, Bioplast, from human or animal fibrin by compression moulding of fibrin and glycerol. It is currently marketed by Ethicon Ltd, Edinburgh, under the registered name Biethium. It is a translucent, yellowish-brown, flexible preparation lending itself readily to implantation (Gerendás, 1959). Horvath et al. (1969) stated that by prior heat-treatment Bioplast loses its antigenic properties, and it causes neither fever nor an immune response. It readily covers the tissues and allows natural or spontaneous healing to occur unobstructed. Bioplast is not incorporated into the repair. By its use regenerative processes in the surrounding tissues are stimulated. Having fulfilled its task, Bioplast is absorbed by enzymatic cellular digestion (Bagdy et al., 1963; Capperauld et al., 1977).

Successful Bioplast implantations have been carried out in various fields of surgery and for a variety of conditions: in neurosurgery (Afra (1960) used Bioplast as a dural substitute); coxitis tuberculosa (Kovács and Gerendás (1961) as a cup prosthesis over the hip joint); liver buffers (Drobni and Dóczy, 1962; Drobni, 1965 and 1969; Wood et al., 1976); osteomyelitis (Winter and Papp, 1964); surgery of the nasal septum (Gyeney, 1973) and the maxilla (Kovács and Kerényi, 1976); and in the management of stress incontinence of urine in women (Horn et al., 1975).

In ophthalmic surgery Grósz et al. (1967, 1968, 1976) were the first to use Bioplast for indenting the sclera in retinal detachment operations. Later Tapasztó $(1973,1975)$ reported the successful

Address for reprints: Dr A. Czigány, Hospital No. 2, Zala County Council, Nagykanizsa, Hungary application of Bioplast to caustic lesions of the conjunctiva and in the surgical treatment of pseudopterygium.

\section{Materials and methods}

Since July 1975, 21 operations have been performed using Bioplast. In 7 cases it acted as a substitute for conjunctiva, and in 14 it was implanted into the edge of the lid.

In 5 cases Bioplast was used for the surgical treatment of recurring pterygium. From a gammairradiated, double over-wrapped piece of Bioplast measuring $10 \times 10 \times 0.2 \mathrm{~mm}$ a small portion is cut to cover the bare area of sclera after removal of a pterygium and secured with $6 / 0$ catgut or $20 / 22$ silk sutures. Bioplast has also been used in totalsurface symblepharon caused by silver nitrate and following extirpation of a conjunctival papilloma.

Intermarginal plastic surgery using Bioplast was carried out in 14 cases, among which 13 were van Milligan operations for entropion. Bioplast was used here instead of the conventional oral mucous membrane.

\section{Results and discussion}

Our experience indicates that Bioplast is easy to handle, as it lends itself readily to cutting and suturing. On the 2 nd to 4 th day after implantation in the conjunctiva it becomes veined and finely granulated, accompanied by the discharge of a small amount of greenish-yellow secretion. From the 5th to 6th day it becomes increasingly difficult to distinguish the implant from its environment, and its borders with healthy conjunctiva are indicated 
only by the sutures. After 30 days the implant cannot be recognised even with a slit lamp.

In no case did we observe infection, rejection, or an allergic reaction. Recovery was perfect both functionally and cosmetically. No recurrence occurred during the 4 to 12 months of observation.

The author thanks Ethicon Ltd, Edinburgh, for supplying the implant material, and Novex Company Ltd, Budapest, for its technical assistance.

\section{References}

Afra, D. (1960). Zentralblatt für Neurochirurgie, 20, 78.

Bagdy, D., Gerendás, M., and Winter, L. (1963). ThrombinFibrin-produkte und ihre therapeutische Anwendung. Fischer: Jena.

Capperauld, I., Lawrie, P., and French, D. A. (1977). Properties of bovine fibrin absorbable implants. Surgery, Gynecology and Obstetrics, 144, 3.

Collin, J. R. O. (1975). British Journal of Ophthalmology, 59, 288.

Drobni, S., and Dóczy, A. (1962). Chirurg, 33, 551.

Drobni, S. (1965). Revue Internationale Hépatologie, 15, 259.

Drobni, S. (1969). Magyar Sebészet, 22 (6), 352.
Gerendás, M. (1959). Therapia Hungarica, 7, 6.

Grósz, I., Orbán, T., and Gerendás, M. (1967). Presse Médocale, 75, 2714.

Grósz, I., Orbán, T., and Gerendás, M. (1968). Szemészet Ophthalmologica Hungarica, 105, 175.

Grosz, I., Vereb, K., and Kerényi, G. (1976). Acta Ophthalmologica, 54, 408.

Gyeney, L. (1973). In: Proceedings of Conference of Experimental Section of Hungarian Society of Surgery.

Horváth, N., Somogyvári, K., Somos, P., and Surján, J. (1969). Acta Veterinaria Academiae Scientiarum Hungaricae, 19, 191.

Horn, Kövér, J., and Marton, I. (1975). British Journal of Obstetrics and Gynaecology, 82, 431.

Kovács, P., and Gerendás, M. (1961). Acta Orthopaedica Scandinavica, 30, 294.

Kovács, B., Kerényi, G. (1976). International Journal of Oral Surgery, 5, 111.

Tapasztó, I. (1973). In: Proceedings of Conference of Experimental Section of Hungarian Society of Surgery.

Tapasztó, I. (1975). In: Proceedings of a meeting of the Hungarian Ophthalmic Society.

Winter, L., and Papp, S. (1964). Die Osteomyelitis und ihre Behandlung. Fischer: Jena.

Wood, C. B., Capperauld, I., and Blumgart, L. H. (1976). Bioplast fibrin buttons for liver biopsy and partial hepatic resection. Annals of the Royal College of Surgeons of England, 58, 401. 